\title{
Indonesian Penal Policy of Information Disorder: The Paradigm Shift
}

\author{
Feby Mutiara Nelson ${ }^{1}$, Vidya Prahassacitta ${ }^{2}$ \\ \{vidya.prahassacitta@binus.ac.id² \\ Faculty of Law, Universitas Indonesia, 16424, Indonesia, ${ }^{1,2}$ \\ Department of Business Law, Bina Nusantara University, 11480, Indonesia ${ }^{2}$
}

\begin{abstract}
Long before information disorder via online become a global problem, Indonesia has criminalized the distribution of information disorder. The prohibition is regulated in article 14 and 15 Law No. 1 the Year 1946 which part of the Indonesia penal law. Punishment for this criminal provision is temporary imprisonment. However, the social context when Law No. 1 the Year 1946 issued is different from the current situation. Therefore, the purpose of this research is to analyses Indonesia's penal policy-related information disorder and whether that penal policy suitable for the current situation and condition where the information disorder becomes faster and massive. Using document research and a comparative approach with Singapore who prohibited this conduct under the Protection from Online Falsehoods and Manipulation Act year 2019, it shows that Indonesia's penal policy requires a paradigm shift to solve the distribution information disorder via online problems without violating the freedom of expression as a fundamental right. In the end, this research has good implications for planning penal policy in the future.
\end{abstract}

Keywords: Penal policy, freedom of expression, information disorder

\section{Introduction}

Distribution of information disorder via the internet becomes Indonesia's criminal problems. Data from the Ministry of Information and Communication of the Republic of Indonesia ("MoIC") confirm 1.028 disinformation contents regarding Covid-19 that distributed from January until August 2020. Then 110 contents were already reported to Indonesia National Police by the MoIC for further criminal investigation in Indonesia, it is a crime to create and distribute information disorder which causes a public nuisance. The prohibition is regulated in article 14 and 15 Law No. 1 the Year 1946 which part of Indonesia penal law. Punishment this criminal provision is temporary imprisonment. However, it raises the question of whether the provision of article 14 and 15 Law No. 1 the Year 1946 is suitable with the current situation and condition?

Previous research analyzed the legal perspective of the internet information disorder but does not specific analyse criminal law matter [1]. Other previous research Analysed regarding the handling of information disorder according to Law Number 1 Year 1946 [2]. Both previous researches does not use a comparative method. It is different from this research which focuses on punishment's purpose of this distribution of information disorder prohibition. This research compares Indonesia criminal law with Singapore which in 2019 issued the Protection from Online Falsehoods and Manipulation Act year 2019. 
The purpose of this article is to analyze Indonesia's penal policy-related information disorder. Does provision on article 14 and 15 Law Number 1 Year 1946 suitable with current condition which technology and communication create convenience to citizen to express and distribute their opinion. Punishment of this prohibition shall consider the balancing between crime control effort and protection of freedom of expression. As mention in Article 19 paragraph 3 International Covenant on Civil and Political Rights which protects the freedom of expression and at the same time, such article also limits the freedom of expression with to respect the rights or reputations of others, to the protection of national security or of public order (order public), or public health or morals.

\section{Method}

The research is a documentary research. The data source comes from previous studies and researches from other researchers [3]. The method that used in this research documents study using legal material, collecting from legislation, books, and journal articles. To complete the data from the internet also uses as an additional source.

The research conducts through three steps. Legal materials that already collected from libraries and the internet, divided into a group according to research questions. Then data analysis micro comparative approaches to answer the research problems. The micro comparative approach also uses to compare several topics or aspects from two or more legal systems [4]. In this research, Singapore is chosen because under the new law Protection from Online Falsehoods and Manipulation Act which was issued in last 2019, Singapore has a new perfective to deal with information disorder distribution. The final step then summarizes the legal answers.

\section{Results and Discussion}

Before presenting the result, first authors shall describe the concepts that uses in this research. In this article, the concept of penal policy refers to a crime control effort using criminal law and punishment parts of this. Penal policy parts of social policy therefore in crime control penal and non-penal efforts shall be integrated [5]. Then, the concept of Information disorder is uses to distinguish inaccurate news which produces and distribute by press institutions. Information disorder consists of three types, disinformation, misinformation, and malformation [6].

\subsection{Presenting the results}

Indonesia and Singapore come from two different legal traditions. Indonesia is part of the civil law system and Singapore is part of the common law system. In general, both legal systems have different characters. One of the basic characteristics of the civil law system is that the court's main task is to apply and interpret the law contained in a code, or a statute to case facts. Code and statute are premier legal sources. Then when certain cases are not regulated by the code, the courts should apply some of the general principles used to fill the gaps. In the common law system, the law is not created utilizing legislation but is based mainly on case law. The principle is that earlier judicial decisions, usually of the higher courts should be followed in the 
subsequent cases. The growing globalisation imposed a need unification of law. In contemporary civil law the role of judges in the creation of law is increasingly important, while the difference between civil law and common law courts shows a tendency of disappearing, or at least looking less significant. On the other hand, large sections of common law have been regulated by statutes and even codes [7]. In this article, the comparation limited only in criminal law regulation that prohibit the fabricate and distribute information disorder.

\subsubsection{Indonesia criminal regulation}

Indonesia prohibition of distribution information disorder on Article 14 and 15 Law Number 1 the Year 1946 regarding Criminal Regulation. Person who violate those regulations shall be punish between two to ten years of imprisonment. The purpose of both articles is to protecting public order and to create stability during post independent declaration [8]. Since both articles do not mention the internet as media to distribute information disorder, in practice law enforcement officer sometime used Article 45A paragraph (2) Law Number 11 the Year 2008 regarding Information and Electronic Transaction which has been amended by Law Number 19 the Year 2016. However, this article does not suitable because this article specifically prohibit person who fabricate and distribute hate speech via internet.

\subsubsection{Singapore criminal regulation}

Singapore under the Protection from Online Falsehoods and Manipulation Act, Singapore distinguishes those conducts. Singapore criminalizes a person who intentionally conducts several activates related to information disorder. The law prohibits the person 1) fabricate and distribute information disorder which creates a social riot. 2) use an inauthentic online account to distribute and to accelerate the information disorder communication. 3) make or alter information disorder with intention of communicating that information. 4) receive any financial or another material benefit for providing any services to communicate information disorder.

Besides under the Protection from Online Falsehoods and Manipulation Act, Singapore introduces a correction direction. It is a government order for a person to correct or to clarify his/her statement in the specified form and manner of communication and by the specified time. If the person does not fulfill its obligation to conduct correction direction, then social media intermediaries should suspend the person's account or block accesses for social media users to the account. Social media intermediaries shall conduct that action as ordered by the Government of Singapore. If social media intermediaries do not comply with the government order shall be punished. In case is an individual the punishment is fine for a maximum of twenty thousand Singapore dollars or twelve months imprisonment or both. In the case is a corporation the punishment is a fine of maximal one million Singapore dollars.

\subsubsection{The similarity and differences between Indonesia and Singapore}

Both countries prohibit person who fabricate and distribute information disorder which disturb public order. Punishment for the perpetrator is imprisonment and/or fine. The perpetrator shall have evil intention when he/she create and distribute the information disorder to public.

Indonesian does not prohibit specific action related the distribution of information disorder via internet. When the person distributes information disorder using a fake account or by hacking other accounts, it considers as part of distribution information disorder activities. Then, it does not matter the motivation of the person to distributing information disorder as long as it 
is conducted intentionally. Different with Singapore who create categories related information disorder that still can be tolerated and not. For the first category, correction direction imposes as a treatment to a person who violates the law. Then information disorder that can't be tolerated and intentionally conducted penal punishment shall be imposed.

\subsection{Discussion}

The debate regarding the penal policy is to find the justification for imposing punishment [9]. Retributive and deterrence are two of that justification. The retributive purpose is to give suffering or sorrow to the perpetrator. It parts of the non-consequentialism view which claims that morality is the justification of punishment and it doesn't matter whether the punishment is right or wrong. Deterrence has a forward purpose which punishment not only considers as an instrument to deliver suffer and sorrow to the perpetrator but also to prevent a person or public from committing a crime. It is a consequentialist view which claims that right or wrong in a moral act will determine the consequences of the action [10]. Furthermore, retributive and deterrence become the aims of the penal policy itself.

Criminal law has characters last resort mean that criminal law is subsidiary and fragmentary. Means criminal law has aimed to complement other laws in crime control and criminal law can only protect the partial person and public interest. Therefore, criminal law is used when other legal and social efforts fail [11]. This principle shall be considered when drafted a penal policy. Retributive and deterrence are part of Indonesia's penal purpose of the prohibition of distribution information disorder. Heavy penalty imposes to create a warning to the public about the suffering and sorrow about the punishment. However, the deterrence itself become debatable due to their lack of success story [12].

A heavy penalty does not reduce the distribution of information disorder. Article 14 and 15 Law No. 1 Year 1946 purpose is to punish the perpetrator. In other hand, other mechanisms also conducted. MoIC conduct media literacy conduct to clarify the information disorder and to take down and blocking the site which distribute the information disorder. However, these mechanisms not in line. Law enforcement officer apply criminal law in the first place without consider that in trivial or mirror information disorder which does not create public nuisance, MoIC mechanism might be sufficient solve the problems.

Indonesia requires a paradigm shift in penal policy, especially on the prohibition of distribution information disorder. Punishment itself can't stop the negative effects of information disorder. The distribution of information disorder via the internet and social media create have contributed to the creation of what has been called 'echo chambers' and 'filter bubbles' that are seen to reinforce individuals' existing views and produce increasingly siloed debates [13].

Singapore under Protection from Online Falsehoods and Manipulation Act has a stronger approach. The purpose of this new regulation is not only to create deterrence effects by criminalizing and punishing the perpetrator but is to maintain neutrality communication among Singapore citizen in an online site by intervention in the communication. Neutrality communication means to stop the information disorder debate among the Singapore citizen and to restore the communication as previous condition. Correction direction is part of the intervention of communication. Under the Protection from Online Falsehoods and Manipulation Act, correction direction follows by internet intermediary's obligation to manage algorithm to distribute the correction or clarification form correction direction in their internet or social media platform. This intervention will minimize the negative effects of distribution information disorder and its parts of preventive action. 
Singapore applies the last resort principle. The person who repeats the create and distribute information disorder even though his/her did not conduct the correction direction and his/her social media account has blocked by internet intermediary, then the criminal charge can apply. In the latest development, the Government of Singapore has ordered Facebook to block access to account Star Time Review for Singapore Facebook users. Star Time Review has a post article containing claims about the coronavirus (Covid-19) situation that according to the Government of Singapore as entirely untrue. Before the order to Facebook, Star Time Review already receive notice for the Government of Singapore to correct their news, but they fail [14].

However, this correction direction idea raises a debate about whether this violates the freedom of expression. Two justification of freedom of expression are to discover the truth and to promote democracy [15]. Both processes require pluralism expression from every citizen. The correction direction supports the government as central which every opinion is justified as truth if the government approved. Level of trust in government in Singapore is highs. According to an Edelman survey published in June 2020, trust in the Government is seventy percent [16]. The correction direction might violate the freedom of expression, but it can stop the debate regarding information disorder among the Singapore citizen. The risk to disturb public order can be minimalized.

It becomes a consideration to Indonesia since Indonesia a democratic country. Indonesia's constitution acknowledges the freedom of expression as a fundamental citizen right. Even thought, the level of trust in Indonesia is highs which publish in October 2020 is sixty-six percent [17], but Indonesia has difference politic context with Singapore. Indonesia is democratic country. Government has strong opposition parties which criticize government policy Therefore, Indonesia citizen does not consider government as central of information. Deference with Singapore, an authoritarian country, criticize government's policy in Singapore is a tabu.

\section{Conclusion}

Indonesia requires a paradigm shift in penal policy related to the distribution of information disorder. Article 14 and 15 Law Number 1 the Year 1946 impose an old paradigm that focuses on retributive and deterrence. Punishment imprisonment and fine does not suitable for the current situation in which distribution becomes more massif. Criminal law is the last resort therefore use of criminal law shall be limited. The government needs to stop the communication regarding the information disorder among the citizens likes Singapore under Protection from Online Falsehoods and Manipulation Act. However, the intervention of communication shall not violate freedom of expression.

\section{Acknowledgements}

This research funding by University of Indonesia Publikasi Terindeks Internasional Prosiding grand year 2020 . 


\section{References}

[1] B. Pratama, D. Mutiara, and M. Broto, "Legal Perspective of the Internet Hoax," no. April, 2019, doi: 10.4108/eai.26-1-2019.2283207.

[2] M. L. Panggabean, "Handling of Hoax News According to Law Number 1 of 1946," Int. J. Adv. Sci. Technol., vol. 29, no. 08, pp. 1275-1287, 2020.

[3] R. A. J. Singleton and B. C. Straits, Approaches to social research, 3rd ed. New York: Oxford Univeristy Press, 1999.

[4] P. De Cruz, Comparative Law in a Changing World. Third Edition. London: Cavendish Publishing Limited, 2007.

[5] G. P. Hoefnagels, The Other Side of Criminology. New York: Springer Science+Business Media, 1973.

[6] Claire Wardle, Information Disorder, no. October. London: FirstDraft, 2019.

[7] C. Pejovic, "Civil Law and Common Law: Two Different Paths Leading to the Same Goal," Victoria Univ. Wellingt. Law Rev., vol. 32, no. 3, p. 817, 2001, doi: 10.26686/vuwlr.v32i3.5873.

[8] H. B. Siong, Verhandelingen Van Het Koninklijk Instituut Voor Taal-, Land- En Volkenkunde An Outline of the Recent History of Indonesian Criminal Law. Berlin: Springer-Science+ Business Media, B. V., 1961.

[9] B. Hudson, Penal Policy and Social Justice. The Macmillan Press, 1993.

[10] V. Tadros, "Criminalization and Regulation," in The Boundaries of the Criminal Law, R. A. Duff, Ed. New York: Oxford University Press, 2010.

[11] N. Jareborg, "Criminalization as Last Resort (Ultima Ratio)," Ohio State J. Crim. Law, vol. 2, pp. 521-534, 2005.

[12] A. Ashworth, Sentencing and Criminal Justice. Cambridge: Cambridge University Press, 2005.

[13] A. Vega Montiel, World Trends in Freedom of Expression and Media Development. Global Report 2017/2018, vol. 7, no. 17. 2018.

[14] Shawn L, "Facebook expresses censorship concerns after blocking Singapore users' access to fake news page.".

[15] L. A. Alexander, "Freedom of Expression," in Encyclopedia of Applied Ethics, R. Chadwick, Ed. Cambridge, Massachusetts: Academic Press, 2012, pp. 339-344.

[16] S. Rekhi, "Trust in Singapore Government up: Edelman poll." https://www.straitstimes.com/asia/trust-in-singapore-government-up-edelman-poll.

[17] Febrianto Adi Saputro and Agus Yulianto, "Naik, Survei Indikator: Kepuasan Publik Terhadap Pemerintah." https://republika.co.id/berita/qif987396/survei-indikator-kepuasan-publik-terhadappemerintah-naik. 